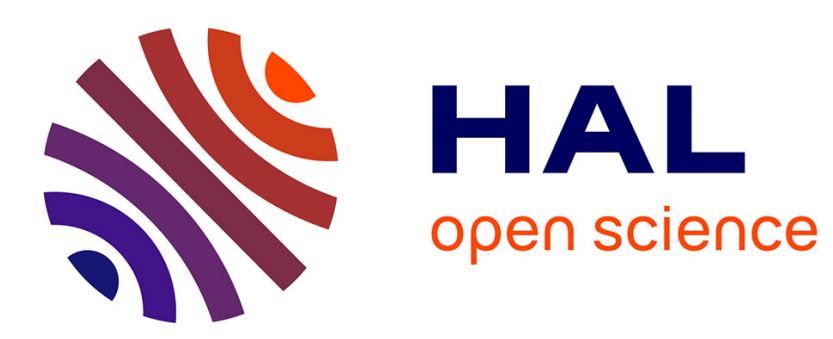

\title{
An evaluation of methods to assess the effect of antimicrobial residues on the human gut flora.
}

\author{
D. E. Corpet
}

\section{To cite this version:}

D. E. Corpet. An evaluation of methods to assess the effect of antimicrobial residues on the human gut flora.. Veterinary Microbiology, 1993, 35 (3-4), pp.199-212. hal-00432164

\section{HAL Id: hal-00432164 \\ https://hal.science/hal-00432164}

Submitted on 13 Nov 2009

HAL is a multi-disciplinary open access archive for the deposit and dissemination of scientific research documents, whether they are published or not. The documents may come from teaching and research institutions in France or abroad, or from public or private research centers.
L'archive ouverte pluridisciplinaire HAL, est destinée au dépôt et à la diffusion de documents scientifiques de niveau recherche, publiés ou non, émanant des établissements d'enseignement et de recherche français ou étrangers, des laboratoires publics ou privés. 


\title{
An evaluation of methods to assess the effect of antimicrobial residues on the human gut flora
}

\author{
Denis E. Corpet \\ Institut National de la Recherche Agronomique Lab. Xénobiotiques, INRA, F-31931 Toulouse, France
}

\begin{abstract}
1. Barrier effect. Relevant models should include an anaerobic dominant flora that antagonizes minor bacterial populations such as drug resistant $E$. coli.

2. Anaerobes vs. aerobes. Aerobe counts are more precise and much less time consuming than anaerobe counts. Minor populations of drug resistant aerobes are sensitive markers of the ecosystem balance, and are directly relevant to the potential risk of antimicrobial residues.

3. MIC vs. plate counts. The determination of minimum inhibitory concentrations ( MIC ) of selected clones is time consuming, does not detect subdominant resistance (less than $1 \%$ ), and the MIC shift is difficult to test statistically. In contrast, direct counts of bacteria on drug supplemented media allows a rapid measure of minor resistant populations.

4. Statistics: Most published designs do not include adequate statistical evaluation. This is critical for trials made in conventional humans and animals, where data are highly variable.

5. Human trials: The lowest concentration of antibiotic tested in human volunteers (2mg oxytetracycline / $\mathrm{d}$ for $7 \mathrm{~d}$ in 6 subjects) significantly increased the proportion of resistant fecal enterobacteria $(\mathrm{P}=0.05)$. However, the huge day-to-day and inter-individual variations of human floras make this evidence rather weak.

6. Gnotobiotic mice inoculated with human flora are living isolated models in which the effect of any antimicrobial on the human gut flora can be tested. This in vivo model does include the barrier effect of dominant anaerobes. Inter-individual and day-to-day variations of bacterial populations are lower in those mice than in humans.

7. Most resistant enterobacteria in the human gut of untreated people come from bacterial contamination of raw foods. The relative contribution of residues in selecting antibiotic resistance seems to be low when compared to bacterial contamination.
\end{abstract}

\section{MICROBIAL EFFECTS OF ANTIMICROBIAL RESIDUES}

Three possible effects might be produced by residues on the gut flora:

\section{Direct risks}

Drug residues might lead to a specific infection by overgrowth of a known enteropathogen (e.g., Salmonella sp., Clostridium difficile) (Tancrede, 1989).

\section{Potential risks}

Drug residues could increase the number of potential pathogens (e.g., Enterobacteria, Pseudomonas aeruginosa ) or of drug resistant bacteria. In healthy people this increase is not harmful, but in people at risk like immuno-compromized patients or patients in intensive care units, those bacteria may lead to opportunistic infections (Corpet, 1989a; Tancrède, 1989). 
Drug resistant commensal bacteria are not harmful either, but most resistant bacteria bear Rplasmid. The increased size of the plasmid reservoir enables more plasmid transfers to pathogens, and could favor the addition of new genes on a pre-existing R-plasmid (Corpet, 1986).

\section{Subtle changes in flora}

Drug residues could induce changes in the flora that are not harmful to present knowledge. Examples are a significant change in the balance between commensal bacteria, whose role is unknown, a small shift in the drug resistance of anaerobes, or a change in some microflora associated characteristics.

These 3 effects may be summarized as a decrease in the barrier effect. This barrier effect is also called bacterial antagonism, antagonistic effect, colonization resistance or competitive exclusion (Tancrède, 1989). The barrier effect means that the strict anaerobes of the dominant indigenous flora prevent the growth of minor aerobes, of R-plasmid carriers, and of bacterial invaders. As a consequence of this barrier effect:

* Some resident bacteria of the gut flora remain at relatively low population levels, when compared with dominant anaerobes, or with population numbers of a single strain in the gut of a germfree animal. For example there are about $10^{7}$ cells of E. coli per gram of stool, while the same strain inoculated alone in a germfree mouse would establish at the level of $10^{10}$ cells per gram of gut content (Freter et al., 1983a).

* Multi-resistant strains, carrying R-plasmids, are generally not resident in the gut. In volunteers given a sterile diet, most resistant enterobacteria are cleared from the gut within a few days (Corpet, 1988a).

* Bacterial invaders, including pathogens, that enter the gut are most often cleared from the gut (Van der Vaaij, 1989 ). Enteric infections can occur only with high infecting doses, or in special people as newborn or antibiotic-treated persons (Tancrède et al., 1977; Holmberg et al., 1984; Van der Vaaij et al., 1986).

* This indirect effect of antimicrobial drugs through the weakening of barrier effect may explain why an antibiotic active against gram-positive organisms may cause a change in the gram-negative population (Gaines et al., 1980).

From those considerations, is clear that any relevant model for the study of gut flora should include an anaerobic dominant flora, since this is probably important in providing a barrier effect against minor bacteria.

\section{QUANTITATIVE STUDIES OF THE FECAL FLORA}

To assess the effect of antimicrobial residues on the gut flora, one could evaluate the following parameters: the dominant anaerobes, the minor aerobes, the antibioresistance characteristics; the resistance of the flora to a challenge by a pathogenic strain, and indirect biochemical markers of bacterial activity.

Fig. 1. Composition of the human fecal flora. Percentage of each genus are given within parenthesis.

\section{Anaerobes}

Anaerobes are by far the dominant bacteria of the gut ecosystem, as

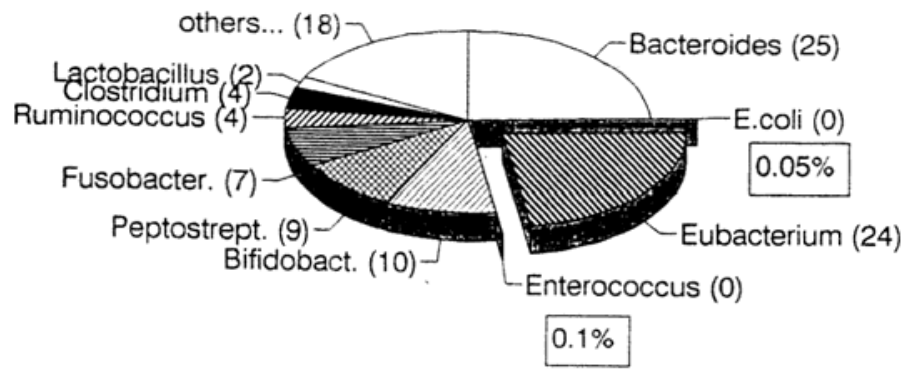


shown on Fig. l. Several hundred species have been reported from the fecal flora, and the cultivable anaerobes constituting $80 \%$ of the bacteria in one human stool belong to 30 different species (Moore and Holdeman, 1974). An ideal approach to assess the effect of an antimicrobial on the composition of gut flora would require the determination and enumeration of those anaerobes, and the determination of their resistance to antimicrobial drugs. However, technical problems make this approach impracticable. The flora has a complex composition, no good selective media for anaerobes are available, species and genus are not precisely defined, and most anaerobes are extremely oxygen sensitive. Therefore the exact determination of the composition of the flora in one fecal specimen is time consuming and rather imprecise. For instance, a specialized laboratory composed of 8 technicians can handle only one specimen per week, and moreover the coefficient of variation of data is at least $10 \%$ and often it is more than 100\% (Moore and Holdeman, 1974; Moore et al., 1978). From a specific study of the Bacteroides fragilis group in 10 volunteers, Meijer-Severs and Van Santen (1986 ) concluded that at least a 3 to 4 log difference from the control sample is required to establish a significant change in anaerobes due to antibiotic treatment (i.e. a 1000 to 10000 fold decrease ). A simplified technique has been proposed, using the morphology of the 96 dominant anaerobic clones from a fecal sample. One may question the ability of this simplified (and still time consuming ) technique to detect a small change in the flora composition, when for example the Bacteroides spp. are represented by only one or two clones in some volunteers (Tancrède and Barakat, 1989). Finally, results obtained with anaerobes are difficult to interpret, since there are usually not enough accurate data to the test the statistical significance of the observed changes, and we lack the background knowledge to tell if the observed effect is clinically relevant.

A micromorphometric technique has been used to assess the effect of ceftriaxone on flora and appears promising. This is the direct digital image analysis of human fecal flora, followed by a principal components analysis of the data (Van der Vaaij, 1989; Meijer, 1991).

\section{Aerobes}

Aerobes (or facultative anaerobes) represent a minor fraction of the human fecal flora, usually less than $1 \%$ of the bacteria. Major aerobes are enterobacteria (principally E. coli ), and enterococci. Species are well characterized, and good selective media are available to count aerobes in fecal flora. Since the techniques are fast and inexpensive they can be used to count aerobes repeatedly and accurately yielding enough data for statistical analysis. Although aerobes are only a small part of the fecal flora, their determination could be a sensitive assessment of the gut ecosystem modification. As can be seen in Fig. 2 an antimicrobial affecting slightly the dominant anaerobes, and decreasing the number of Bacteroides sp. from 25 to 24\% could permit a 2000\% increase in the number of E. coli. The change in the Bacteroides sp. population would be undetectable, while the change in the $\mathrm{E}$. coli population would be easy to detect. Some aerobes are potential pathogens, and could harbor plasmids and transposons that are directly infectious for pathogens: changes in aerobe counts following antimicrobial residues are hence directly related to public health problems.

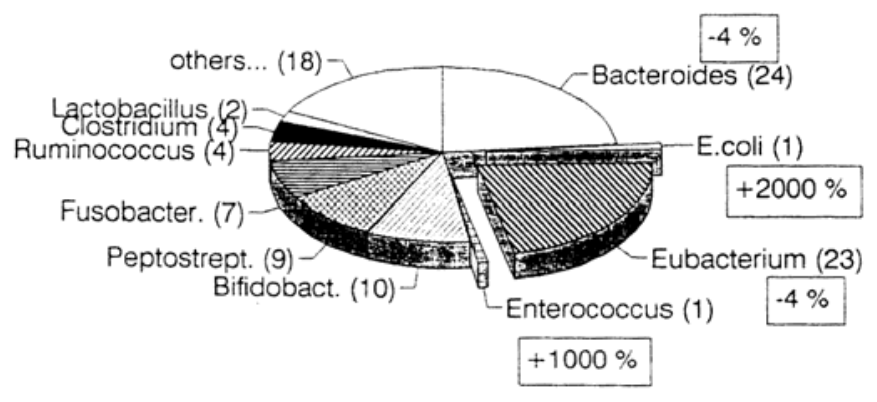

Fig. 2. Speculative effect of an antimicrobial on the composition of the human fecal flora. Per-cent changes for one genus are given in boxes. 


\section{Antibioresistance}

The antibioresistance characteristics of anaerobes and of aerobes can be determined in two ways: (1) a direct count of bacteria resistant to a given antimicrobial at a given concentration (breakpoint). (2) the determination of minimum inhibitory concentrations ( MIC ) of selected clones. The first method is fast, and permits the accurate determination of minor populations of resistant bacteria. However the choice of the breakpoint concentration for resistance is critical and must be based on previous data or pilot study. The second method, MIC, is time consuming, does not allow the accurate quantification of minor resistant populations (not enough selected clones), nor the detection of resistance when the ratio of total/resistant population is more than 1000 . The statistical analysis of MIC shift is usually done by testing only the median MIC in control and treated flora. Only MIC determinations can detect a change far from the breakpoint (e.g., a doubling in the MIC of resistant bacteria, but with no change in their population number ) .

Resistant populations of aerobes are sensitive markers of the modifications of the flora by antimicrobial drugs. Since bacteria resistant to the drug under study are not affected by the drug, their increase in number would reflect indirectly other perturbations of the ecosystem, either in the susceptible populations of the same species ( selection ), or in other bacteria (barrier effect modifications). Finally, an increase in the resistant population size, corresponding to an increased size of the R-plasmid reservoir, is directly related to public health.

Thus, the proportion of resistant enterobacteria appears to be simple and sensitive marker of gut flora changes under drug treatment.

\section{Pathogen challenge}

The barrier effect of a flora can be directly assessed by following the elimination of a known bacterial inoculum (Ducluzeau et al., 1970; Koopman et al., 1987). For instance, inocula containing $10^{8}$ living cells of E. coli, Shigella flexneri, Salmonella typhimurium, Vibrio cholerae, Pseudomonas aeruginosa, Campylobacter jejuni, Staphylococcus aureus, Clostridium difficile, C. perfringens, or Candida albicans were given to mice, and the number of organisms surviving in the gut 15 days later was compared in control and in drug treated animals (Andremont et al. 1983; Pecquet et ai. 1991). This kind of study appears to be directly relevant to public health, but the sensitivity to low antimicrobial doses is unknown. The technique of the oral challenge with an exogenous pathogen is easy to perform in experimental animals, particularly in isolators, but would be unethical in human.

\section{Indirect biochemical markers}

A number of biochemical markers of the activity of the flora have been proposed, including the measure of beta-glucuronidase, 7-alpha-dehydroxylation of bile acids, conversion of cholesterol to coprostanol, mucin breakdown, short chain fatty acid production and degradation of beta-aspartylglycine (Midtvedt, 1986). Though they can be measured accurately, biochemical measurements are at best only indirectly related to the barrier effect, observed changes cannot be interpreted in terms of public health.

\section{EXPERIMENTAL METHODS}

Methods used to assess the effects of antimicrobial residues on gut flora include: testing in vitro the effect of antimicrobial on pure strains, and administration of antimicrobial agents in vivo to conventional animals, to human volunteers or to gnotobiotic mice. 
Tests in vitro

* Lorian and de-Frietas (1979) measured the minimum antibiotic concentrations of antimicrobial drugs on pure strains, estimated by altered morphology or decreased growth rate. They showed that most antimicrobial drugs remain active at concentrations 10 times lower than the MIC.

* Brady et al. (1988 ) made daily sequential inoculations of flasks containing antimicrobial with a pure bacterial strain. They showed that $0.1 \mu \mathrm{g}$ tetracycline/ml "selected" a phenotype of increased resistance to most antibiotics, while $1 \mathrm{mg} / \mathrm{ml}$ of other antibiotics had no effect. The test does not seem to be relevant since the assessment of resistance is not genotypic, and the selection among a pure strain differs greatly from the selection conditions in an ecosystem.

* Brady and Katz (1988 ) measured the mating between E. coli clones in a flask containing an antimicrobial for $18 \mathrm{~h}$ and determined the percent transfer rate. They observed almost no effect of low antimicrobial concentrations, except lug tylosin/ml (shift of transfer rate from 57 to $80 \%$ ). However, since the transfer rates in vivo are between $10^{-14}$ and $10^{-16}$, one may question the relevance of their observation to the in vivo situation (Corpet, 1986).

* Lebek and Egger (1983 ) studied the effect of antimicrobial drugs in an $8 \mathrm{~h}$ continuous flow culture of $3 \mathrm{E}$. coli strains, one of which carried an R-plasmid. In this chemostat, concentrations around one tenth of the MIC of tetracycline, chloramphenicol, and gentamicin were sufficient to favor the R-plasmid bearing E. coli. The experimental system mimics in some ways the digestive transit, and a kind of simplified barrier effect is obtained from the competition between E. coli strains. This model however lacks the ecological conditions in vivo (antimicrobial metabolism, anaerobiosis, substrate limitation, growth rate), and was later invalidated in vivo, by testing the same strains in the gut of gnotobiotic mice (Corpet and Lumeau, 1987).

The major drawback of those in vitro systems is the absence of the gut ecosystem, hence they cannot test the effect of residues on the barrier effect. This problem could theoretieally be overcome, by culturing the fecal flora in che-mostat (Miller and Wolin,1981; Freter et al., 1983b; Corpet, 1989b). but this approach seems no simpler than the model using germfree mice contaminated with human fecal flora.

Tests in vivo in conventional animals

Antimicrobial have been tested at residue concentrations in conventional rodents, and in beagle dogs. A number of studies were also carried out in farm animals given growth promoting antimicrobials, at levels ranging from 5 to $50 \mathrm{ppm}$ of the diet.

* Conventional rodents are considered unacceptable because their gut flora is very different from the human one, particularly since the number of $E$. coli is very low in mice and rats. Attempts were made to provide E. coli cells continuously in the drinking water of rats, or to expose the rats to an environment highly contaminated with E. coli. These rodent models proved to be unsatisfactory for determining the no-effect level of an antimicrobial on the gut flora (Rollins et al., 1975).

* The feeding of certain antimicrobial as feed additives to chickens, pigs or calves result in a population of resistant fecal E. coli. However the baseline incidence of resistant bacteria is high in farm animals, even after a 10 years without antibiotic use (Langlois et al., 1986). Therapeutic treatments or inter-group cross contaminations are difficult to avoid in farm animals studies (Linton et al., 1975). Moreover, natural changes in bacterial populations in the gut of chicken and pig interfere with any possible drug effect (Linton et al., 1985) 
* Rollins et al. (1975), and Gaines et al. $(1978,1980)$ fed groups of 5-7 beagle dogs for 35-57 d with residue doses of oxytetracycline, dihydrostreptomycin, penicillin or virginiamycin. Total and resistant coliforms were counted in 5 to 10 samples from each animal, and compared to levels in control untreated dogs. In these well designed experiments, the baseline level of resistance was low and contamination was avoided by housing groups in separate buildings. However the inter-animal and day-to-day variability of the flora was high (e.g., standard deviation > mean, Gaines et al., 1980 ), leading to a low ability to detect an effect. Dogs, like other animals, harbor some bacteria resembling those in humans, but when detailed analyses are done it is evident that most of the bacterial species in the different animals are not the same as those in humans (Moore et al., 1978). Moreover, the drug metabolism is not the same in dogs and humans. However, this model seems the best acceptable one amongst conventional animal models, to test in vivo the effect of drug residues on a complex flora.

\section{Human volunteer trials}

* Nord et al. (1985, and 1993 elsewhere in this issue of Vet. Microbiol.) gave per os therapeutic doses of a number of antimicrobial drugs to groups of 10 patients for $7 \mathrm{~d}$. According to their data the drugs that are fully absorbed from the gut, and that cannot be detected in the stools, do not change any measured parameter of the fecal flora (including anaerobe counts, and antibioresistant bacteria). Provided the methods are sensitive enough (detection threshold and statistical power), it is reasonable to postulate that residues of the drugs that produced no detectable effect at therapeutic doses cannot affect the gut flora.

* Goldberg et al. (1961), and Knothe (1963 ) gave daily doses of oxytetracycline to 25-50 volunteers, for 2-6 months. They did observed a sporadic increase of resistant enterobacteria in volunteers given $10 \mathrm{mg}$ per day (resistance increase in $30 \%$ of the subjects, $\mathrm{P}<0.01$; Goldberg et al., 1961) . The no-effect level was not determined, and sampling was not frequent enough to detect a small change in a highly fluctuant parameter.

* In volunteers given residue doses of ampicillin (Corpet, 1987), or oxytetracycline (Tancrede and Barakat, 1989), no firm conclusion could be drawn due to of a lack of design power. Two mg of oxytetracycline per day produced no detectable effect on the gross composition of the 96 dominant anaerobes, and no apparent shift in the MIC of 6x96 clones of anaerobes (no statistics were given). However, the percentage of resistant enterobacteria increased $(\mathrm{P}<0.01)$ in 2 volunteers out of 5 given ampicillin $(1.5 \mathrm{mg} / \mathrm{d}$ for $21 \mathrm{~d} .17$ data pairs per subject ), and in the 6 others given oxytetracycline $(2 \mathrm{mg} / \mathrm{d}$ for $7 \mathrm{~d}$. 1 data pair per subject) $(\mathrm{P}=0.05$, median increase 30 -fold).

Because of contamination from food, the concentration of resistant $E$. coli in feces varies enormously in humans (Corpet, 1987, 1988a). Thus a possible effect of antimicrobial drugs could be hidden by the natural fluctuations in resistant populations of fecal bacteria. A relevant trial in human would require a high number of volunteers and a long monitoring period. Power-based assessments of sample size are not easy to do since data are not distributed normally (Mann et al., 1991) . However, a posteriori calculations show that 14 and 33 volunteers respectively would have been necessary to reach a $\mathrm{P}=0.01$ significance in the trials of Tancrède and Barakat (1989), and Corpet (1987) (Corpet, 1988c, p.43).

Advantages of human trials are obvious, since no inter-species extrapolation has to be made. Major drawbacks are the difficulty of testing a drug not cleared for use in human, and the requirement to use high number of volunteers and to monitor each one for a long time, to overcome the variability in the fecal resistant populations. 


\section{Gnotobiotic mice}

Gnotobiotic mice are living isolated models where the effect of antibiotics can be studied in the absence of contamination (Corpet, 1980; Corpet, 1984; Corpet, 1988b).

* The minimum antibiotic levels for selecting a resistance plasmid was determined in dixenic mice, i.e. germfree mice harboring two isogenic E. coli strains, one of which was carrying an R-plasmid (Corpet and Lumeau, 1987). A strong correlation between antimicrobial dose and selection of the resistant $E$. coli clone was observed in 70 groups of 3 dixenic mice. Minimum selecting doses were in the range 1-10 mg/1 of drinking water (Corpet et al., 1989). However, this model lacks the dominant anaerobic flora that provides the barrier effect in human gut.

* The gross composition of the anaerobic flora, the barrier effect and the other major functions of the flora in the human gut are present in the gut of human flora associated mice (Raibaud et al., 1980; Hazenberg et al., 1981; Andremont et al., 1983; Ducluzeau et al., 1984; Mallet et al., 1987; Corpet, 1989b). The human flora associated mice have been used extensively to assess the in vivo effect of therapeutic doses of antimicrobial on the human gut flora com-position, and on the resistance to pathogen challenges (Hazenberg et al., 1982; Andremont et al. 1983; Pecquet et al. 1986, 1987, 1991).

* Human flora associated mice can be used to test in vivo the effect of antimicrobial residues on human flora. In a typical trial, 20 germfree mice are first inoculated with a strain of $B$. fragilis of human origin, to reduce the oxygen and substrate concentrations in the gut. Fecal samples from 4 human donors are diluted a hundred-fold anaerobically, pooled, introduced in the isolator and given by gavage to the 20 mice within 30 min after passing. The barrier effect was not fully transferred to the mice when the germfree mice were not preinoculated with a $B$. fragilis strain, or when the fecal human flora was frozen $\left(-85^{\circ} \mathrm{C}\right.$ in prereduced $50 \%$ glycerol) before its transfer to the mice (Corpet, 1991, unpublished data). A week after the flora transfer, mice are randomized to 4 isolators. Each group is given continuously for 30-40 d a drinking bottle containing either pure water (negative control), or a selecting dose of the antimicrobial under study (positive control), or residue concentrations. Total and resistant enterobacteria and/or enterococci are monitored daily in the pooled mice feces, in order to get 15 to 20 data points per group. Numbers and proportions of resistant bacteria in treated groups are compared with control groups by a matched-pair non-parametric rank test. Data show that the flora is the same in recipient mice and human donor, and in different individual mice as well as different untreated groups of mice. In human flora associated mice, $0.5 \mathrm{mg} / 1$ of chlortetracycline or ampicillin was enough to increase 30-fold the resistant population of fecal E. coli $(\mathrm{P}<0.005)$ (Corpet, 1987).

This model is easy to handle, yields clear cut data for statistical analysis, and meets the following prerequisites: (1) a low base-line of resistant bacteria, (2) no difference between the different groups before treatment, (3) no contamination during the trial, and hence a low day-to-day variability in resistance levels (4) a flora similar to the human flora, including a barrier effect and interactions in vivo. This model seems sensitive to the effect of low antimicrobial concentrations, possibly more than its human counterpart (Corpet, 1987).

Potential drawbacks are the following: (1) the model flora is similar to human flora, but it is impossible to prove they are identical. (2) the results depend on the initial donor flora. The use of a pool from several donors helps to normalize the flora, but unless a standardized human flora is defined, the repetition of an experiment will never be certain (Corpet, 1988b). (3) the model does not include the variability of human flora (due to age, illness, drug treatment, and contaminations by new plasmids ). However, the same drawback exists in human trials. (4) the drug metabolism could be different in mice and human, and (5) 
the fecal drug concentrations in the mice must be assayed and related to concentration in human intestine.

\section{EFFECTS OF DIETARY CONTAMINATION ON HUMAN FLORA}

A sterile diet was given to 7 healthy volunteers for 2.5 weeks, after a control period of 3 weeks. During both periods, total and antibiotic resistant lactose-fermenting enteric organisms were counted daily in their stools. A drastic drop in the fecal concentration of ampicillin, tetracycline and streptomycin resistant bacteria was observed during the sterile diet period (see Table 1) . It is concluded that, in the normal human population, most resistant enterobacteria in feces come from contaminated food (Corpet, 1988a). The dayto-day increase in the number of resistant enterobacteria could be 1000000 , due to the ingestion of a contaminated food (see Fig. 3).

Fig. 3. Log No. of lactose-fermenting enteric organisms in the in stools of a volunteers given a sterile diet from days 21 to 40

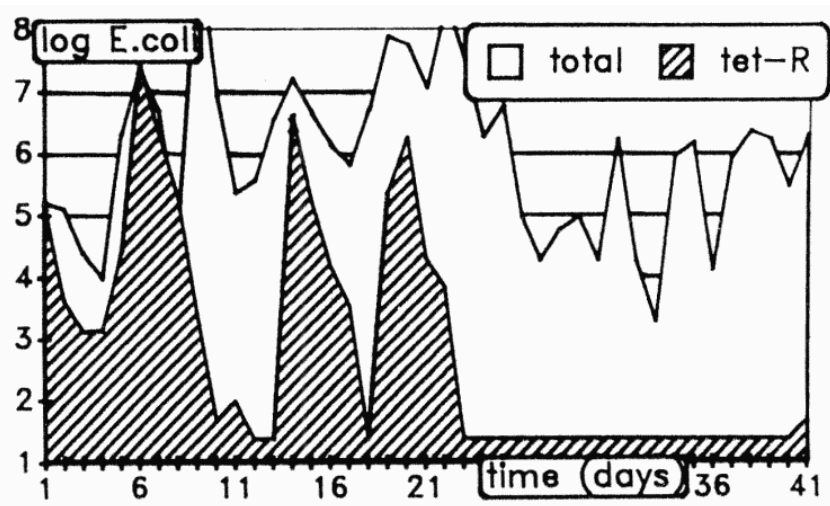

TABLE 1

Resistant lactose-fermenting enteric bacteria in stools of volunteers eating a sterile diet

\begin{tabular}{|c|c|c|c|c|}
\hline Volunteer & Diet & \multicolumn{3}{|c|}{ Log no. of bacteria/g resistant to: } \\
\hline & & ampicillin & tetracycline & streptomycin \\
\hline $\mathrm{A}$ & control & $3.3 \pm 1.7 \mathrm{a}$ & $4.1 \pm 1.8$ & $4.1 \pm 1.8$ \\
\hline & sterile & $1.4^{\mathrm{b}} \pm 0.1^{* *}$ & $1.4 \pm 0.1^{* *}$ & $1.4 \pm 0.0^{* *}$ \\
\hline $\mathrm{B}$ & control & $2.8 \pm 1.4$ & $4.8 \pm 1.3$ & $3.7 \pm 1.6$ \\
\hline & sterile & $1.4 \pm 0.1^{*}$ & $1.7 \pm 0.7^{* *}$ & $1.4 \pm 0.0^{* *}$ \\
\hline $\mathrm{C}$ & control & $4.3 \pm 2.6$ & $2.9 \pm 2.5$ & $2.8 \pm 1.8$ \\
\hline & sterile & $1.6 \pm 0.6^{* *}$ & $1.7 \pm 0.8^{* *}$ & $1.7 \pm 0.9^{*}$ \\
\hline $\mathrm{D}$ & control & $5.2 \pm 2.0$ & $5.7 \pm 1.5$ & $4.9 \pm 1.6$ \\
\hline & sterile & $1.8 \pm 1.0^{* *}$ & $2.3 \pm 1.7^{* *}$ & $1.8 \pm 0.7^{* *}$ \\
\hline $\mathrm{E}$ & control & $2.3 \pm 0.9$ & $4.0 \pm 1.3$ & $3.6 \pm 1.4$ \\
\hline & sterile & $2.0 \pm 0.8$ & $2.7 \pm 1.2^{*}$ & $3.3 \pm 1.7$ \\
\hline $\mathrm{F}$ & control & $7.4 \pm 1.0$ & $7.5 \pm 1.0$ & $7.7 \pm 0.8$ \\
\hline & sterile & $5.0 \pm 0.6^{* *}$ & $5.3 \pm 1.0^{* *}$ & $7.5 \pm 0.6$ \\
\hline $\mathrm{G}^{\mathrm{c}}$ & control & $2.7 \pm 2.0$ & $2.7 \pm 1.0$ & $4.8 \pm 1.6$ \\
\hline & sterile & $6.2 \pm 2.0^{*}$ & $7.6 \pm 0.6^{* *}$ & $7.5 \pm 0.5^{*}$ \\
\hline total & control & $4.7 \pm 1.7$ & $5.2 \pm 1.3$ & $5.0 \pm 1.4$ \\
\hline$($ except G) & sterile & $2.3 \pm 1.3^{*+}$ & $2.5 \pm 1.4++$ & $2.9 \pm 2.3^{*}$ \\
\hline
\end{tabular}

a Mean results of 21 daily counts ( control ) or 17 counts ( sterile ) \pm SD.

b Counts below the detection limit (25 CFU /g ) were converted to 1.4.

c To cure a urinary infection, volunteer $\mathrm{G}$ was given $1 \mathrm{~g} / \mathrm{d}$ of pipemidic acid for 6 days between the two periods. Significance of the difference between the control and sterile periods in the same individual: ${ }^{* *} \mathrm{P}<0.001,{ }^{*} \mathrm{P}<0.01$ (Mann-Whitney test, based on a mean number of 38 daily counts per volunteer). $++\mathrm{P}<0.001,+\mathrm{P}<0.05$ (paired Student t test, based on 6 pairs). 


\section{CONCLUSION}

The mean increase in resistance in volunteers given $2 \mathrm{mg}$ of oxytetracycline was 30 -fold (Tancrède and Barakat, 1989). In mice with human flora given $0.5 \mathrm{mg}$ chlortetracycline or ampicillin the mean increase in resistant population numbers was also 30-fold. Tentatively extrapolated to human, those concentrations are in the high range of residue levels possibly found in human food (Corpet, 1987). Thus antibiotic residues due to veterinary treatments might have a statistically significant effect on gut flora. However, the relative contribution of selecting residues seems low when compared with bacterial contamination.

In our opinion and according to current knowledge, antimicrobial residues are not likely to have a meaningful effect on general public health.

\section{REFERENCES}

Andremont, A., Raibaud, P., Tancrede C., 1983. Effect of erythromycin on microbial antagonisms: a study in gnotobiotic mice associated with a human fecal flora. J. Infect. Dis., 148: 579-587.

Brady, M.S., Katz, S.E., 1988. Method to determine effect of antibiotics at residue levels on R-factor transfer. J. Assoc. Off. Anal. Chem., 71: 299-301.

Brady, M.S., Strobel, R. J., Katz, S.E., 1988. In vitro analytical system for determining the ability of antibiotics at residue levels to select for resistance in bacteria. J. Assoc. Off. Anal. Chem., 71: 295-298.

Corpet, D.E., 1980. Influence de faibles doses de chlortetracycline sur la resistanee a la chlortetracycline de Escherichia coli dans le tube digestif de souris axeniques hebergeant des flores complexes d'enfant, de veau ou de porcelet. Ann. Microbiol. (Inst. Pasteur)., 131 B: 309-318.

Corpet, D.E., 1984. The effect of bambermycin, carbadox, chlortetracycline and olaquindox on antibiotic resistance in intestinal coliforms : a new animal model. Ann. Microbiol. (Inst. Pasteur)., 135 A: 329-339.

Corpet, D.E., 1986. Ecological factors influencing the transfer of plasmids in vive and in vitro, J. Antimicr. Chemother., 18 sup.C: $127-132$.

Corpet, D.E., 1987. Antibiotic residues and drug resistance in human intestinal flora. Antimicrob. Agents Chemother., 31: 587-593.

Corpet, D.E., 1988a. Antibiotic resistance from food. New Engl. J. Med., 318: 1206-1207.

Corpet, D.E., 1988b. R-plasmid transfer and antimicrobial residues in gnotoxenic animal models. J. Toxicol. Clin. Exper., 8: 21-34.

Corpet, D.E., 1988c. Resistance aux antibiotiques des bacteries intestinales de l'homme: origine non iatrogene. PhD Thesis. Universite Paris Sud. (online access: http:/fcorpet.free.fr/Denis/These.html )

Corpet, D.E., 1989a. Les microbes font de la resistance. La Recherche., 20: (215) 1388-1390. Corpet, D.E., 1989b. Microbial ecology of the intestine. In vitro, in vivo and mathematical models., Rev. Sci. Tech. Off. Int. Epiz., 8: 391-403.

Corpet, D.E., Lumeau, S., 1987. Antibiotic residues and R-plasmid selection : are in vitro methods good models?. Zbl. Bakt. Hyg., 264 A: 178-184.

Corpet, D.E., Lumeau, S., Corpet, F., 1989. Minimum antibiotic levels for selecting a resistance plasmid in a gnotobiotic animal model. Antimicrob. Agents Chemother., 33: 535-540.

Ducluzeau, R., Bellier, M., Raibaud, P., 1970. Transit digestif de divers inoculums bacteriens introduits Per Os chez des souris axeniques et holoxeniques (conventionnelles): effet antagoniste de la microflore du tractus gastro-intestinal. Zentralbl. Bakteriol. Parasitenkd. Infektionskr. Hyg., 213: 533-548.

Ducluzeau, R., Ladire, M., Raibaud, P., 1984. Effet de l'ingestion de son de ble sur la flore microbienne fecale de donneurs humains et de souris gnotoxeniques receveuses, et sur les effets de barriere exerces par ces flores a l'egard de divers microorganismes potentiellement pathogenes. Ann. Microbiol. (Inst. Pasteur)., 135 A: $303-$ 318.

Freter, R., Brickner, H., Fekete, J., Vickerman, M.M., Carey, K.E., 1983a. Survival and implantation of Escherichia coli in the intestinal tract. Infect. Immun., 39: 686-703.

Freter, R., Stauffer, E.. Cleven, D., Holdeman, L.V., Moore, W.E.C., 1983b. Continuous-flow cultures as in vitro models of the ecology of large intestinal flora. Infect. Immun., 39: 666-675.

Gaines, S.A., Rollins, L.D., Silver R.P., Washington, M., 1978. Effect of low concentrations of dihydrostreptomycin on drug resistance in enteric bacteria. Antimicrob. Agents Chemother., 14:252-256.

Gaines, S.A., Rollins, L.D., Williams, R.D., Selwyn, M., 1980. Effeet of penicillin and virginiamycin on drug resistance in lactose-fermenting enteric flora. Antimicrob. Agents Chemother., 17: 428-433.

Goldberg, H.S., Goodman, R.N., Logue, J.T., Handler, F.P., 1961. Long-term, low-level antibiotics and the emergence of antibiotic-resistant bacteria in human volonteers. Antimicr. Agents Chemother., 1961: 80-87. 
Hazenberg, M.P., Bakker, M.; Verschoor-Burggraaf, A., 1981. Effects of the human intestinal flora on germfree mice. J. Appl. Bacteriol., 50: 95-106.

Hazenberg, M.P., Bakker, M., Both-Patoir, H.C., Ruseler-van-Embden, J.G.H., and Schroder, A.M., 1982. Effect of sulfasalazine on the human intestinal flora. J. .Appl. Bacteriol., 52: 103-107.

Holmberg, S.D., Osterholm, M.T., Senger, K.A., Cohen, M.L., 1984. Drug-resistant salmonella from animals fed antimicrobials, New Engl. J. Med., 311: 617-b22.

Knothe, V.H., 1963. Darmfiora und Antibiotika unter besonderer Berucksichtigung der Tetracycline. Deut. Med. Wochenschr., 88: 1469-1477.

Koopman, J.P., Van Der Brink, M.E., ... and Nagengast, F.M., 1987. Influence of the antibiotics roxithromycin and erythromycin on the gastro-intestinal ecology of mice. Z. Versuchstierkd., 30: 79-83.s

Langlois, B.E., Dawson, K.A., Cromwell, G.L., Stahly, T.S., 1986. Antibiotic resistance in pigs following a 13 years ban. J. Anim. Sci., 62 Supp1.3: 18-32.

Lebek, G., Egger, R.. 1983. R-Selection of subbacteriostatic tetracycline concentrations. Zbl. Bakt. Hyg. I Abt. Orig., A 255: 340-345.

Linton, A.H., Howe, K., Osborne, A.D., 1975. The effects of feeding tetracycline, nitrovin and quindoxin on the drug-resistance of coli-aerogenes bacteria from calves and pigs. J. Appl. Bacteriol., 38: 255-275.

Linton, A.H., Hinton, M.H., Al-Chalaby, Z.A.M., 1985. Monitoring for antibiotic resistance in ecterococci consequent upon feeding growth promoters active against gram-positive bacteria. J. Vet. Pharmacol. Ther., 8: $62-70$.

Lorian, V., De-Freitas, C.C., 1979. Minimal antibiotic concentrations of aminoglycosides and beta-lactam antibiotics for some gram-negative bacilli and gram-positive cocci. J. Infect. Dis., 139:599-603.

Mallet, A.K., Bearne, C.A., Rowland, LR., Farthing, M.J.G., Cole, C.B., Fuller, R., 1987. The use of rats associated with a human faecal flora as a model for studying the effects of diet on the human gut microflora. J. Appl. Bact., 63: 39-45.

Mann, M.D., Crouse, D.A., Prentice, E.D., 1991. Apprapriate animal numbers in biomedical research in light of animal weifare considerations. Lab. Anim. Sci., 41: 6-14.

Meijer, B.C., 1991. Image analysis of gut microflora. PhD Thesis. Rijksuniversiteit Groningen, The Netherland. Meijer-Severs, G.J., Van Santen, E., 1986. Variations in the anaerobic faecal flora of ten healthy human volunteers with special reference to the bacteroides fragilis-group and clostridium difficile. Zbl. Bakt. Hyg., A 261: 43-52.

Midtvedt, T., 1986. Effects of antimicrobial agents upon the functional part of the intestinal flora. Scand. J. Infect. Dis., Supp 1.49 :85-88.

Miller, T.L., Wolin, M.J., 1981. Fermentation by the human large intestine microbial commu-nity in an in vitro semicontinuous culture system. Appl. Environ. Microbiol., 42: 400-407.

Moore, W.E.C., Holdeman, L.V., 1974. Human fecal flora : the normal flora of 20 Japanese Hawaüans. Appl. Microbiol., 27: 961-979.

Moore, W.E.C., Cato, E.P., Holdeman, L.V., 1978. Some current concepts in intestinal bacteriology. Am. J. Clin. Nutr., 31: S33-S42.

Nord, C.E., Heimdahl, A., Kager, L., 1986. Antimicrobial induced alterations of the human oropharyngeal and intestinal microflora. Scand. J. Infect. Dis., Suppl 49 :64-72.

Pecquet, S., Andremont, A., Tancrede, C., 1986. Selective antimicrobial modulation of the intestinal tract by norfloxacin in human volunteers and in gnotobiotic mice associated with a human fecal flora. Antimicrob. Agents Chemother., 29: 1047-1052.

Pecquet, S., Chachaty, E., Tancrede, C., and Andremont, A., 1991. Effects of roxithromycin on fecal bacteria in human volunteers and resistance to colonization in gnotobiotic mice. Antimicrob. Agents Chemother., 35: 548552.

Raibaud, P., Ducluzeau, R., Dubos, F., Hudault, S., Bewa, H., Muller, M.C., 1980. Implantation of bacteria from the digestive tract of man and various animals into gnotobiotic mice. Am. J. Clin. Nutr., 33: 2440-2447.

Rollins, L.D., Gaines, S.A., Pocurull, D. W., Mercer, H.D., 1975. Animal model for determining the no-effect level of an antimicrobial drug on drug resistance in the lactose-fermenting en-teric flora. Antimicrob. Agents Chemother., '7: 661-665

Tancrede, C., 1989. Flore intestinale et pathologie infectieuse humaine. Rev. sci. tech. Off. int. Epiz., 8: 405415.

Tancrede, C., Azizi, P., Raibaud, P., Ducluzeau, R., 1977. Consequences de la destruction des barrieres ecologiques de la flore du tube digestif par les antibiotiques. Perturbations des relations entre l'hote et les bacteries potentiellement pathogenes. Med. Mal. Infect., 7: 145-149.

Tancrede, C., Barakat, R., 1989. Ecological inpact of low doses of oxytetracycline on human intestinal microflora. J. Vet. Med., 42: Supp 35-39 
Van der Vaaij, D., 1989. Bioregulation of the digestive tract microflora. Rev. Sci. Tech. Off. Int. Epiz., 8:-333345.

Van der Vaaij, D., de Vries-Hospers, H.G., Welling, G.W., 1986. The influence of antibiotics on gut colonization. J. Antimicrob. Chemother., 18 C: 155-158. 